Malaysian Journal of Social Sciences and Humanities (MJSSH)

Volume 4, Issue 7, November 2019

e-ISSN : 2504-8562

Journal home page:

www.msocialsciences.com

\title{
Hubungan Pengurusan Kokurikulum dengan Penglibatan Pelajar dalam Aktiviti Kokurikulum Sekolah Menengah
}

\author{
Sheila Michael' ${ }^{1}$ Abdul Said Ambotang1 \\ 1Fakulti Psikologi dan Pendidikan, Universiti Malaysia Sabah (UMS) \\ Correspondence: Sheila Michael (ivyandrew@yahoo.com)
}

\begin{abstract}
Abstrak
Kertas konsep ini bertujuan membincangkan tentang pengurusan kokurikulum dengan penglibatan pelajar dalam aktiviti kokurikulum sekolah menengah. Penglibatan pelajar dalam aktiviti kokurikulum mampu membentuk keperibadian pelajar secara keseluruhannya. Hal ini mampu diserlahkan melalui pengurusan kokurikulum yang cemerlang. Pengurus kokurikulum memainkan peranan besar dalam menjayakan penglibatan tersebut. Kecemerlangan penglibatan pelajar berkait rapat dengan pengurusan kokurikulum. Semakin tinggi pengurusan kokurikulum dilaksanakan dengan cemerlang, semakin besar kesannya kepada penglibatan pelajar. Pelaksanaan pengurusan adalah berdasarkan objektif dan keupayaan pelajar bagi meningkatkan pengetahuan, kemahiran dan nilai yang dipelajari. Justeru, pengurusan kokurikulum mempunyai perkaitan dengan penglibatan pelajar dalam aktiviti kokurikulum.
\end{abstract}

Kata kunci: pengurusan kokurikulum, penglibatan pelajar, aktiviti kokurikulum, pelajar sekolah menengah

\section{The Relationship Between Co-curricular Management and Secondary School Student Involvement in Co-Curricular Activities}

\begin{abstract}
This concept paper aims to discuss the relationship between co-curricular management with student involvement in secondary school. Student involvement in co-curricular activities can shape the overall personality of the students. This can be highlighted through excellent co-curricular management. Cocurricular managers play a key role in the success of the engagement. Student engagement excellence is closely related to co-curricular management. The higher co-curricular management effectiveness is, the greater impact it has on student engagement. The implementation of management is based on the objectives and capabilities of the students to enhance the knowledge, skills and values learned. Therefore, co-curricular management is related to student involvement in co-curricular activities.
\end{abstract}

Keywords: co-curricular management, student involvement, co-curricular activities, secondary school students 


\section{Pengenalan}

Dalam era pembangunan yang berkembang pesat tanpa batasan, Malaysia perlu memastikan matlamat wawasan negara yang sentiasa diimpikan selama ini tercapai. Wawasan yang ingin mewujudkan negara maju mengikut acuannya sendiri memerlukan pengorbanan dan usaha yang gigih daripada masyarakat. Hal ini disebabkan, wawasan tersebut hanya akan dapat dicapai sekiranya rakyat Malaysia mampu melahirkan generasi yang berilmu pengetahuan, berketrampilan, berakhlak mulia, bertanggungjawab kepada diri, masyarakat, agama dan negara. Dengan itu, tanggungjawab untuk memenuhi dan melahirkan generasi tersebut telah diletakkan di bahu institusi pendidikan sejak dari awal lagi dan telah termaktub di dalam Falsafah Pendidikan Kebangsaan. Maka, sistem pendidikan negara secara tidak langsung memainkan peranan yang penting dalam mencapai wawasan negara.

Pelbagai usaha yang telah dan sedang giat dilakukan dalam bidang pendidikan di Malaysia. Dalam pada itu, antara usaha yang telah dilakukan ialah mengadakan kegiatan kokurikulum dalam semua peringkat institusi pendidikan di Malaysia. Sang (2008) menyatakan bahawa kokurikulum dijalankan di sekolah adalah bertujuan untuk menyemai, memupuk dan menanam perasaan espirit de corps, iaitu perasaan kekitaan yang wujud di antara murid berbilang kaum di sekolah, melatih pelajar untuk bertanggungjawab, berdisiplin, berdikari, serta berkemahiran dalam sesuatu bidang yang mereka sertai berdasarkan Laporan Kabinet 1979. Ab. Alim (2004) dan Tam (2010) mendakwa bahawa kokurikulum memainkan peranan yang penting kerana ianya bertujuan untuk merealisasikan pengetahuan, pengalaman dan kemahiran merentasi kurikulum yang boleh diperolehi melalui aktiviti pendidikan jasmani, seni dan reakreasi, aktiviti sains dan teknologi serta aktiviti kumpulan dan sosial. Di samping itu, kokurikulum juga dapat memberi peluang kepada murid untuk membina kekuatan jasmani, meningkatkan keupayaan mental dan membantu dalam kestabilan emosi.

Marjohan dan Mohd Sufian (2007) berpendapat aktiviti kokurikulum merupakan salah satu kaedah untuk membentuk perkembangan personaliti pelajar. Hal ini kerana, aktiviti kokurikulum dapat membantu murid untuk berfikiran positif dan mempunyai semangat berpasukan yang tinggi. Malah, menurut Nur Izza dan Wan Hanim (2014), melalui aktiviti kokurikulum di sekolah, pelajar dapat mengembangkan beberapa domain penting iaitu domain intelek dan domain personaliti. Berdasarkan Pelan Pembangunan Pendidikan (2013-2025), pihak kementerian telah menetapkan bahawa setiap pelajar perlulah menyertai sekurang-kurangnya satu sukan, satu kelab dan satu unit beruniform di sekolah. Program ini bertujuan untuk membina bakat, memupuk minat dan membentuk kemahiran kepimpinan dalam kalangan pelajar sekolah. Ini penting dilaksanakan agar penglibatan pelajar dalam kegiatan kokurikulum dapat ditingkatkan.

Oleh itu, bagi memastikan tujuan dan matlamat kokurikulum yang dilaksanakan tercapai, pelbagai pihak perlu bekerjasama untuk menjayakannya terutama di peringkat sekolah. Oleh yang demikian, pengurusan dan pelaksanaan kokurikulum di peringkat sekolah haruslah dijalankan dengan sistematik dengan bantuan dan kerjasama daripada pihak pentadbir sekolah serta guru agar matlamat untuk melahirkan individu yang selaras dengan kehendak Falsafah Pendidikan Kebangsaan dapat dipenuhi. Walau bagaimanapun, bagi memastikan keberkesanan kokurikulum yang diadakan di sekolah, penglibatan pelajar perlulah diberikan perhatian oleh guru dan pihak pentadbir sekolah. Hal ini bagi memastikan objektif aktiviti kokurikulum yang diadakan dapat dicapai secara menyeluruh.

\section{Pengurusan Kokurikulum}

Mary Parker Follett dalam Samuel (1996) mendapati bahawa pengurusan merupakan sebuah seni untuk melaksanakan sesuatu kerja melalui usaha atau kerjasama manusia untuk mencapai matlamat yang ditetapkan. Selain itu, istilah pengurusan juga dianggap sebagai suatu proses yang berterusan ke arah pencapaian matlamat organisasi mengikut cara yang berkesan dan cekap (Aizzat et al, 2006). Perspektif Olum (2004) menggambarkan pengurusan adalah suatu seni atau sains untuk mencapai matlamat melalui manusia. Istilah pengurusan boleh dikaitkan dengan empat perkara utama, iaitu pengurus akan menjalankan kerja-kerja pengurusan yang meliputi perancangan, pengorganisasian, pembahagian tugas, mengetuai dan pengawalan. Selain itu, pengurusan juga diaplikasikan dalam 
semua jenis organisasi dan pada semua setiap tahap. Tambahan lagi, tujuan semua pengurus adalah sama iaitu untuk meningkatkan produktiviti yang menekankan keberkesanan dan efisyen.

Penetapan yang disarankan oleh pihak kementerian di mana pengurusan kokurikulum dan sukan yang melibatkan aktiviti perlu dijalankan dengan cekap dan berkesan bagi memastikan sekolah berfungsi sebagai institusi pembelajaran dalam melahirkan murid yang seimbang dari segi intelek, rohani, emosi dan jasmani. Oleh itu, bagi mencapai hasrat tersebut, pengurusan kokurikulum di sekolah haruslah melibatkan perkara berikut dalam menguruskan aktiviti kokurikulum di sekolah:

i. Ketetapan bagi memastikan kepatuhan dan keselarasan pelaksanaan kokurikum dan sukan.

ii. Kelab dan persatuan diurus untuk memastikan penglibatan pelajar secara menyeluruh dan sebagai pengukuhan terhadap pembelajaran di bilik darjah.

iii. Badan beruniform diurus untuk memastikan penglibatan pelajar secara menyeluruh dan sebagai pengukuhan terhadap pembangunan perwatakan pelajar dari segi intelek, rohani, emosi, jasmani dan sosial.

iv. Program Sukan untuk semua diurus untuk memastikan penglibatan pelajar secara menyeluruh dan sebagai pengukuhan terhadap pengetahuan, kemahiran dan pembangunan sahsiah pelajar.

v. Program Sukan untuk kecemerlangan sekolah diurus untuk mengesan dan memperkembangkan bakat serta potensi pelajar ke arah peningkatan pencapaian sukan sekolah

\section{Penglibatan Pelajar dalam Aktiviti Kokurikulum Sekolah Menengah}

Astin (1984) mengukur penglibatan pelajar dalam aktiviti kokurikulum iaitu sejauh mana interaksi fizikal dan psikologi dalam mendapatkan pengalaman kokurikulum. Dia mengakui terdapat empat unsur penting iaitu:

i. Penglibatan menjurus kepada penglibatan tenaga fizikal dan psikologi dalam pelbagai aktiviti yang benar-benar boleh dirumuskan.

ii. Tanpa mengira apa jua objeknya, penglibatan tetap berlaku berterusan. Penglibatan pelajar adalah berbeza untuk setiap individu walaupun dalam aktiviti yang sama.

iii. Penglibatan mempunyai ciri kuantitatif dan kualitatif. Sejauh mana penglibatan pelajar dalam aktiviti kokurikulum boleh diukur melalui dua aspek iaitu secara kuantitatif atau kualitatif.

iv. Banyaknya penerimaan pembelajaran pelajar dan perkembangan kendiri berkaitan dengan mana-mana program kokurikulum sama ada ia sesuai dengan kuantiti atau kualiti penglibatan.

Selain itu, penglibatan adalah proses sosialisasi pemahaman dan pembelajaran tentang cabaran, tuntutan, keperluan, faedah dan ganjaran di persekitaran pelajar (Kuh, 1992). Manakala Leithwood dan Jantzi (1999) mentakrifkan penglibatan kepada dua dimensi iaitu afektif dan tingkah laku. Melalui penglibatan dalam kokurikulum, pelajar mempunyai peluang membina dan membangunkan potensi diri yang menjurus bidang pekerjaan pada masa hadapan serta meningkatkan hubungan dan kemesraan. Tambahan pula, mereka berpeluang mempelajari budaya dan adat resam tentang sesuatu keadaan. Kesan daripada itu, pelajar dapat menjadi peserta yang aktif dan bukan sekadar menjadi seorang pemerhati yang pasif. Selain itu, Russell et al. (2005) menyatakan penglibatan ialah satu tenaga dalam tindakan, iaitu sesuatu yang menghubungkan seseorang dengan aktiviti. Penglibatan yang dinyatakan ini adalah terdiri daripada tiga bentuk, iaitu tingkah laku, emosi dan kognitif. Fredericks, et al. (2004) pula menjelaskan mengenai penglibatan pelajar dari sudut emosi, tingkah laku dan kognitif. Penglibatan pelajar dari segi emosi iaitu sama ada pelajar menunjukkan reaksi positif atau negatif terhadap guru, rakan kelas, akademik dan sekolah. Pandangan Chapman (2003) pula menggambarkan penglibatan pelajar sebagai kesediaan pelajar untuk mengambil bahagian dalam aktiviti rutin di sekolah, sama ada penglibatan secara kognitif, tingkah laku dan petunjuk berkesan penglibatan pelajar dalam tugasan pembelajaran tertentu. Seterusnya, Yazzie-Mintz (2007) merumuskan bahawa penglibatan pelajar dilihat dari tiga aspek, iaitu kognitif, intelektual atau 
akademik. Dalam kes ini, penglibatan pelajar dalam aktiviti kokurikulum dilihat dengan menilai jumlah masa melibatkan diri, jumlah aktiviti yang disertai, jumlah jawatan yang dipegang, kekerapan menjalankan tugas dan penilaian aktiviti kokurikulum.

Kokurikulum juga dikenali sebagai gerakerja kokurikulum (GERKO) merupakan aktiviti pendidikan yang dirancang dan diperlaksanakan selepas waktu pelajaran formal di dalam dan di luar bilik darjah, berasas dan lanjutan pelajaran sesi persekolahan. Ianya merupakan sebahagian daripada kurikulum formal di luar sukatan pelajaran yang merangkumi aktiviti-aktiviti persatuan, kelab, permainan dan sukan, serta unit beruniform. Selain itu, pelaksanaan aktiviti kokurikulum bertujuan untuk mengembangkan potensi, bakat dan kepimpinan pelajar dalam bidang jasmani, sosial, kebudayaan dan khidmat masyarakat, di samping membentuk sahsiah dan sikap yang positif dalam kalangan pelajar (Sang, 2008).

\section{Pengurusan Kokurikulum dengan Penglibatan Pelajar dalam Aktiviti Kokurikulum Sekolah Menengah}

Menyedari akan kepentingan menjalankan aktitivi kokurikulum yang berkesan, banyak kajian-kajian yang terlah dijalankan untuk mengenal pasti keberkesanan dan kelemahan dalam pengurusan kokurikulum di institusi pendidikan. Berdasarkan kajian yang dijalankan oleh Hairul dan Melati (2013) mendapati terdapat hubungan yang positif di antara peranan pengurus kokurikulum dengan jumlah penglibatan murid dalam aktiviti kokurikulum yang dijalankan. Selain itu, pengurus kokurikulum yang mempunyai kemahiran mengurus aktiviti yang baik akan menarik minat murid untuk menyertai aktiviti kokurikulum yang dijalankan kerana pengurus tersebut pada kebiasaanya dapat menjalankan aktiviti yang menarik dan sistematik.

Kajian yang dijalankan oleh Norlena, Muhd Taib dan Nur Asmara (2013) pula mendakwa keberkesanan pengurusan aktiviti kokurikulum adalah bergantung dengan kompetensi guru tersebut menguruskan aktiviti. Tambahan pula, guru-guru didapati mempunyai kompetensi yang tinggi dalam aspek pengetahuan, perancangan, pelaksanaan dan penilaian aktiviti kokurikulum. Namun, kompetensi guru dalam pengurusan kokurikulum yang tertinggi adalah penilaian, diikuti dengan pelaksanaan dan pengetahuan, manakala guru mempunyai kompetensi yang terendah bagi aspek perancangan. Hasilnya menunjukkan bahawa dalam pengurusan kokurikulum, guru-guru mempunyai kelemahan untuk merancang aktiviti kokurikulum di sekolah. Berbeza dengan kajian yang dijalankan oleh Tay (2004) yang mendapati bahawa penguasaan guru terhadap aspek dalam kemahiran pengurusan kokurikulum adalah baik termasuklah kemahiran merancang melaksana dan memantau.

Selain itu, kajian daripada Wan Shamsudin dan Saufi (2007) telah mendapati aktiviti kokurikulum yang dijalankan di sekolah adalah bersifat tradisional dan dijalankan atas dasar meneruskan aktiviti yang telah dilakukan sejak dahulu lagi tanpa sebarang pembaharuan dan penambahbaikan untuk memenuhi keperluan masa kini. Malah, kajian ini juga mendapati aktiviti kokurikulum di sekolah hanya untuk memenuhi keperluan dan arahan pentadbir sekolah yang telah dirancang mengikut takwim tahunan sekolah. Malahan, terdapat juga aktiviti kokurikulum yang dijalankan secara mengejut tanpa skema pelaksanaan seperti perancangan, pelaksanaan, pemantauan dan penilaian. Hal ini menyebabkan matlamat aktiviti kokurikulum terhadap murid dan sekolah tidak dapat dicapai.

Tambahan lagi, latar belakang guru juga memberikan pengaruh ke atas pengurusan kokurikulum di sekolah. Kajian yang dilakukan oleh Fauzi et al. (2014) menggambarkan bahawa tahap pengetahuan guru baharu bekaitan pengurusan kokurikulum adalah tinggi. Hal ini disebabkan guru baharu telah mahir melakukan pengurusan aktiviti semasa di peringkat universiti. Malah, guru baharu juga didapati lebih aktif dan bertenaga jika dibandingkan dengan guru lama. Walau bagaimanapun, kajian ini mendapati wujud hubungan yang lemah di antara tahap pengetahuan guru dengan kebolehan mereka merancang aktiviti kokurikulum di peringkat sekolah. Hal ini menunjukkan bahawa tahap pengetahuan guru baharu berkaitan pengurusan kokurikulum hanya memberikan pengaruh yang sedikit terhadap kebolehan mereka untuk menguruskan kokurikulum terutama pada peringkat perancangan dan pelaksanaan di sekolah. 
Fischer dan Theis (2014) membuktikan bahawa terdapat hubungan di antara aktiviti kokurikulum yang berkualiti dengan penglibatan pelajar dalam aktiviti kokurikulum di sekolah. Pelaksanaan aktiviti kokurikulum yang berkualiti dapat memberikan motivasi positif kepada pelajar untuk melibatkan diri dalam pelbagai aktiviti kokurikulum. Hal ini dapat melahirkan persepsi yang positif dalam kalangan pelajar terhadap aktiviti yang dijalankan. Walau bagaimanapun, kajian ini juga mendapati bahawa motivasi pelajar adalah komplek dan berkait rapat dengan tingkahlaku mereka. Selain pengaruh latar belakang dan status akademik pelajar, penglibatan dalam aktiviti kokurikulum juga turut dipengaruhi oleh persepsi pelajar terhadap aktiviti yang dijalankan (Al-Ansari et al., 2015).

\section{Rumusan}

Umumnya, konsep dalam kertas ini membincangkan pengurusan kokurikulum dan penglibatan pelajar dalam aktiviti kokurikulum sekolah menengah. Ini sekaligus menggambarkan bagaimana kedua-dua konstruk ini dapat mempengaruhi perkembangan pelajar khususnya di sekolah menengah. Kesan daripada itu, pelbagai kajian telah dibuat sama ada dalam mahupun luar negara bagi mengkaji hubungan pengurusan kokurikulum dengan penglibatan pelajar dalam aktiviti kokurikulum sekolah menengah. Pengurusan kokurikulum yang cemerlang mampu meningkatkan penglibatan aktiviti kokurikulum pelajar seterusnya membentuk keperibadian diri yang lebih positif. Oleh itu, kertas konsep ini diharapkan dapat membantu dalam menambahkan lagi ilmu pengetahuan serta membuka peluang kepada penyelidik lain untuk dijadikan sumber kajian khususnya dalam pendidikan.

\section{Rujukan}

Ab.Alim, A. R. (2004): Pengurusan Gerak Kerja Kokurikulum. Selangor: Penerbit Oxford Sdn. Bhd.

Al-Ansari, A., Al-Harbi, F., Abdelaziz, W., \& Abdelsalam, M. (2015). Factors affecting student participation in extra-curricular activities: A comparison between two Middle Eastern dental schools. The Saudi Dental Journal.

Aizzat M. N., Intan, O., \& Zainal, A. A. (2006). Pengantar Pengurusan. Universiti Sains Malaysia: Utusan Publications \& Distributors Sdn. Bhd.

Astin, A. (1984). "Student Involvement: A Developmental Theory for Higher Education." Journal of College Student Personnel.

Chapman, E. (2003). Alternative approaches to assessing student engagement rates Practical Assessment, Research and Evaluation 8 (13).

Fauzi, H., Yahya, D., Mohd Sofian, O. F., Yaakob, D., Arumugan, R., Ismail, H. A., Muhamadul, B. Y. (2014) Co-Curricular Management Practices Among Novice Teachers in Malaysia. Asian Journal of Education And E-Learning (ISSN: 2321 - 2454).

Fischer, N., \& Theis, D. (2014). Quality of extracurricular activities - Considering developmental changes in the impact on school attachment and achievement. Journal for Educational Research, 6(3), 54-75.

Fredericks, J. A., Blumenfeld, P. C. \& Paris, A. H. (2004). School engagement: Potential of the concept, state of the evidence. Review of Educational Research 74: 59-109.

Hairul, N., \&. Melati, Y. (2013). The Effectiveness of Administration and Cocurriculum in Sport to the Involvement of Students. International Journal of Science and Research (IJSR), 264-269.

Kementerian Pelajaran Malaysia. (2010). Standard Kualiti Pendidikan Malaysia: Jemaah Nazir dan Jaminan Kualiti: Putrajaya.

Kuh, G. D. (1992). What do we do now? Implication for educations of how colleges affects students. American Educational Research Journal 30(2): 277-304.

Leithwood, K. \& Jantzi, D. (1999). The relative effects of principal and teacher sources of leadership on student engagement with school. Educational Administration Quarterly, 35 (5): 679-706.

Marjohan, J. \& Mohd Sofian, O. F. (2007). Developing human value through extra curricular activities. The Journal of Human Resource and Adult Learning 3(1). 
Norlena Salamuddin, Mohd Taib \& Nur Asmara Diana (2011). Teachers' Competency in School Extracurricular Management. World Applied Sciences Journal 15 (Innovation and pedagogy for lifelong learning):49-55.

Nur Izza Ainaa, M. R. \& Wan Hanim Nadrah, W. M. (2014). Leadership of Technical Students Through Co-Curriculum Activities in University. Journal of Management Policies and Practices Vol. 2, No. 2, Pp. 39-43.

Olum, Y. (2004). Modern Management Theories and Practices. Kampala-Uganda: Makerere University.

Russell, V. J., Ainley, M., \& Frydenberg, E. (2005). Schooling Issues Digest: Student Motivation and Engagement.

Samuel, S. (1996). Mary Parker Follett--Prophet of Management: A Celebration of Writings from the 1920's. Academy of Management. The Academy of Management Review, 21(3), 863.

Sang, M. S. (2008). Pengurusan Kokurikulum dan Pendidikan Sukan. Puchong: Penerbitan Multimedia Sdn. Bhd.

Tam, Y. K. (2010): Pengurusan Kokurikulum. Kuala Lumpur: Kumpulan Budiman Sdn. Bhd.

Wan Shamsuddin \& Saufi. (2007). Intipati Tersirat dalam Skop dan Peranan Guru Penolong Kanan Kokurikulum. Institut Aminuddin Baki: KPM.

Yazzie-Mintz, E. (2007). Voices of students on engagement: A report on the 2006 High School Survey of Student Engagement. Bloomington: Center for Evaluation \& Education Policy, Indiana University. 